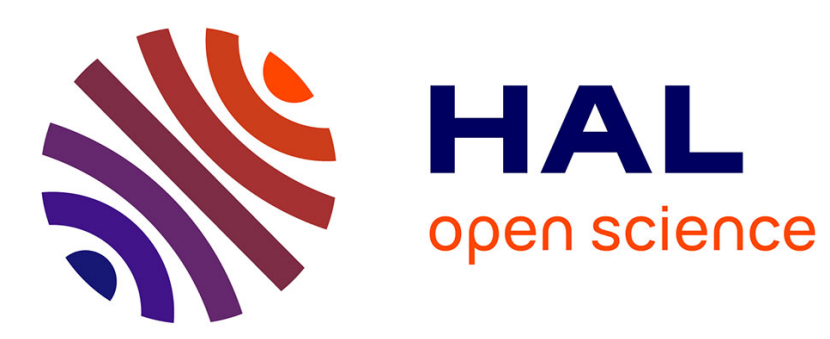

\title{
The Role of Narrative in Communicating Science
} Lucy Avraamidou, Jonathan Osborne

\section{To cite this version:}

Lucy Avraamidou, Jonathan Osborne. The Role of Narrative in Communicating Science. International Journal of Science Education, 2009, 31 (12), pp.1683-1707. 10.1080/09500690802380695 . hal-00516243

\section{HAL Id: hal-00516243 \\ https://hal.science/hal-00516243}

Submitted on 9 Sep 2010

HAL is a multi-disciplinary open access archive for the deposit and dissemination of scientific research documents, whether they are published or not. The documents may come from teaching and research institutions in France or abroad, or from public or private research centers.
L'archive ouverte pluridisciplinaire HAL, est destinée au dépôt et à la diffusion de documents scientifiques de niveau recherche, publiés ou non, émanant des établissements d'enseignement et de recherche français ou étrangers, des laboratoires publics ou privés. 


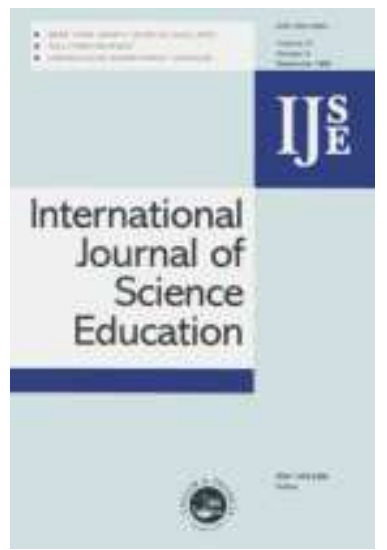

\section{The Role of Narrative in Communicating Science}

\begin{tabular}{|r|l|}
\hline Journal: & International Journal of Science Education \\
\hline Manuscript ID: & TSED-2008-0016.R2 \\
\hline Manuscript Type: & Research Paper \\
\hline Keywords: & position paper \\
\hline Keywords (user): & narrative, science education \\
\hline \multicolumn{2}{|l}{} \\
\hline
\end{tabular}

\section{S) ScholaroNE \\ Manuscript Central}




\section{Abstract}

This theoretical paper attempts to make the case for the use of narrative (i.e., fictional

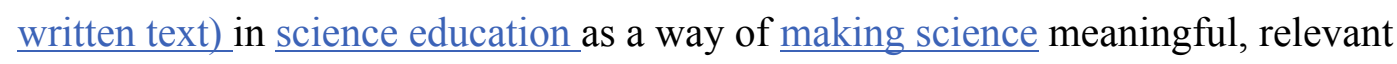
and accessible to the public. Grounded in literature pointing to the value of narrative in supporting learning and the need to explore new modes of communicating science, this paper explores the use of narrative in science education. More specifically, in this paper we explore the question: What is narrative and what are its necessary components that may be of value to science education? In answering this question we propose a view of narrative and its necessary components, which permits narrative a role in science education, and, is in fact, the main contribution of this paper. Also, a range of narrative text examples are offered in the paper to make the case for a representation of fictional narrative in science. In order to address questions connected with the use of narrative in science education, a research agenda based on perspectives on narrative implications for learning, is framed. 
The Role of Narrative in Communicating Science Introduction

Reform documents in contemporary science education criticize the way science has been portrayed and taught in schools (AAAS, 1993; NRC, 2000). Lemke (1990) commenting on the way in which science is portrayed in the curriculum, noted that:

In teaching the content of the science curriculum, and the values that often go with it, science education, sometimes unwittingly, also perpetuates a certain harmful mystique of science. That mystique tends to make science seem dogmatic, authoritarian, impersonal, and even inhuman to many students. It also portrays science as being much more difficult than it is, and scientists as being geniuses that students cannot identify with. It alienates students from science (p. xi).

This picture of science, mysterious and opaque, estranges students because it is disconnected from their everyday experiences. It portrays science as a set of objective truths and absolute realities to be approached - abstracted, disembodied and decontextualized. In short, it presents science as dogma - a body of uncontroversial, unquestioned and unequivocal knowledge (Claxton, 1991). In this picture, students are positioned outside the theories; they are like spectators, looking in, while theory is presented as a map drawn by experts to depict 'what is there' (Middleton, 1995).

Much of this alienation can be attributed to the 'foreign' nature of the language that constitutes science itself. A major feature of such genres is the excision of the personal. Meyer (1998) argues that within the science learning context are situated constructions of meaning that are dependent upon the surrounding discourse, however, there are a number of obstacles to scientific discourse such as "its formal nature, the vernacular is unheard of, and comfortable patois has no place" (p. 467) As Halliday and Martin's (1993) functionalist analysis of scientific language has shown, the language, grammar and genres of science have evolved to provide effective and efficient communication within the scientific community. Not surprisingly, acquiring this discourse of science requires a long and arduous apprenticeship.

Montgomery (1996), discussing the discourse of science, noted that the use of "technical language sets up a barrier between those who can speak and understand 
and those who cannot" (p. 7), which causes exclusion and makes science inaccessible to the public. As he commented, "the language of science is the tongue of foreigners, equally exotic whether spoken in the narrative hut of the laboratory or the villages and cliff-dwellings of the professional meeting" (p. 9). The technical nature of the language of science (i.e., use of scientific vocabulary, definitions, terms, theories) not only makes it hard to understand scientific concepts but it also reflects specific messages about its nature and, in particular, that science is for the experts - the scientists, as only they are the ones that can understand this language.

Another problem confronting science is that its discourse is cumulative. As Tallis (1995) argues:

The reader of a scientific paper is entering a conversation that has been going on for over 2000 years. Each step in science builds on the last - as E. M. Forster pointed out, science progresses in a fundamental sense, which art does not - so its discourse inescapably deviates increasingly from that of everyday life, except inasmuch as it feeds back into and changes everyday discourse. Moreover, science deviates from the discourse of everyday life in that its language increasingly becomes multi-semiotic. The graphs, symbols and diagrams of the modern scientific paper do not merely serve an additional supplementary illustration; rather they are an integral to its communicative function. As a result, an expanding industry of knowledge intermediaries or science communicators has developed to provide 'translations' between the discourse of science and the language of the public.

For those who view science education as a pre-professional training for the would-be scientist, the language of science is not problematic. School science deals in the foundations of science whose content has remained largely unchanged, and textbooks present science and its membership as a formal objective guild (Meyer, 1998). However, the gulf between school science and contemporary science is a source of student disaffection; typified by the following comment:

The blast furnace, so when are you going to use a blast furnace? I mean, why do you need to know about it? You're not going to come across it ever. I mean look at the technology today, we've gone onto cloning, I mean it's a bit away off from the blast furnace now, so why do you need to know it? (Author, 2001, p. 449). 
Moreover, the gulf between school science and contemporary science becomes evident within the context of socioscientific issues, such as, the use of genetically manipulated organisms (GMO) in agriculture, the mad cow disease, the global climate change and others. Decisions in this arena are too often reliant on subjective and emotional criteria rather than the subject of informed debate ${ }^{1}$. Enabling young people to make informed decisions does not require an education that will turn them all into scientists, but it does mean providing them with a broad understanding of the major scientific explanations, how scientific knowledge is generated and validated, its limitations, some consideration of its social implications and a deeper understanding of the nature of risk and its assessment. Just as the study of English literature aims to develop a critical appreciation of what are the significant elements of good writing, we argue that the aim of science education should be to develop students' understanding of the intellectual and creative achievements of the scientific endeavour, their knowledge and skills needed to engage in public debate, and the ability to evaluate critically media reports of science (Author, 1998). In order to achieve these goals and communicate the ideas of science and its achievements, we believe it becomes necessary to explore new modes of communicating science.

\section{Forms of scientific text}

A review of the literature indicates four main forms of text used to communicate science: expository text, argumentative text, narrative, and a mixture of narrative and expository text. The most common is the traditional form of expository text found in many textbooks. Its major features, although not a necessary feature of expository text in general, are that it is univocal, non-dialectic and its major focus is either descriptive or explanatory. Such texts commonly deploy the genres, language and grammar of science and are difficult to read (Author, 2001). Expository text itself consists of a mixture of types. There is, for instance, expository text, which provides a causal mechanism for how a rainbow is produced or how inherited

\footnotetext{
$1 \quad$ A good example is the recent controversy surrounding the use of the triple vaccine for Measles, Mumps and Rubella (the MMR vaccine). Because of one paper published in 1999 suggesting that there might be a correlation between this vaccine and autism, a significant number of parents have declined to have their children vaccinated. The numbers taking this decision are now large enough to risk a new epidemic of any one of these diseases. Moreover, the author of the original paper has now retracted it indicating that the evidence on which the claim was based is now flawed.
} 
characteristics are transmitted from one generation to the next. There is also expository text that simply presents a description of the scientific picture of the bones of the body or the parts of the flower.

Less familiar within science education is the second form of text argumentative text. A study done by Penney, Norris, Phillips and Clark (2003) analysing the textual characteristics of junior high school science textbooks and comparing them to media reports of science showed that there was no argumentative text in the textbooks. In fact, the results of this study indicated that junior high school science textbooks expose students to large amounts of expository text instead.

Argumentative texts are texts that fundamentally take a dialectical approach seeking to make the case that a given claim is true reasoning forward from the premise to the conclusion. The conclusion, however, can be debated, and consequently such arguments are often hedged with a metadiscourse of meaning associated with words like 'may', 'could' or 'possibly'. The third type of text is narrative text, which is used to form 'narratives of science' and 'narratives of nature'. In the narratives of science, scientists develop a claim, which is supported by a series of data. In contrast, popularising articles present 'narratives of nature' in which plants or animals are the subjects and their activities are presented in a story-form, and not in a claim-data form.

The fourth type of text is narrative text in which expository text is embedded. Such text is commonly used by popularisers of science for the purpose of stimulating the interest and holding the attention of the reader. One such exemplar is Chapter 5 of the book The Blind Watchmaker, by Richard Dawkins, an evolutionary biologist. This chapter begins with the memorable quotation "It is raining DNA outside". Dawkin goes on to describe a willow tree that is shedding fluffy seeds far and wide across the landscape. The paragraph ends: "It is raining instructions out there; it's raining programs; it's raining tree-growing, fluff-spreading algorithms. That's not a metaphor, it is the plain truth. It couldn't be any plainer if it were raining floppy disks". This kind of written text - narrative - is most common in everyday discourse and lies at the heart of the account of this paper.

\section{Common Discourse as Narrative}

Of the four forms of scientific text, most common in everyday discourse, is 
narrative ${ }_{2}$ not expository. Our lives are told and represented through narratives; history is of itself a narrative, albeit contested and with plural accounts; literature is the embodiment of narrative with it classic genres of romance, irony, tragedy and comedy; others contend that economics is enriched by the narrativist perspective, as our law and the social sciences. This would suggest, as White (1981) argues:

That far from being one code amongst many that a culture may utilize for endowing experience with meaning, narrative is a metacode, a human universal on the basis of which transcultural messages about the nature of shared reality can be transmitted (p. 1).

Stories are used every day as a way of making sense of and communicating events in the world. Movies, books, televisions and everyday conversations are filled with the telling of stories (Shank \& Berman, 2002). Stories are essentially a sub-set of the narrative genre and describe a series of actions and experiences made by a number of real or imaginary characters (Ricoeur, 1981). According to Shank and Berman (2002), a story is, "a structured, coherent retelling of an experience or a fictional account of an experience... and that in some sense, all stories can be considered didactic in nature, in that they are intended to teach or convey something to the listener" (p. 288). Likewise, in a book aptly entitled Teaching as Storytelling, Egan (1986) makes the case that stories form a natural vehicle and means of educating students not only about their cultural and historical roots but also about the scientific descriptions of 'reality'.

Stories then are a vehicle through which experiences and events are communicated amongst people. Researchers have contended that stories have the potential to influence people's understandings and beliefs, and essentially, promote a societal and cultural change (Brock, Shank \& Berman, 2002; Strange \& Green, 2002). Brock et al., (2002) argued that the impact of stories on people's beliefs and behaviours is enormous, citing the impact of the best-selling books like Uncle Tom's Cabin. As they stated, "it is very hard to make the case that any rhetorical presentation of the $19^{\text {th }}$ century had an impact that was even remotely comparable to that of the fictional narrative" (p. 3). According to Schank and Berman (2002), “for communication, memory and learning purposes, stories are likely to be richer, more compelling, and more memorable than the abstracted points we ultimately intend to convey or learn when we converse with others" (p. 293). 
A legitimate question becomes one of whether and how can stories, as in fiction text, be used in science education. Put otherwise, how can the complex grammar of science reliant on distinctive genres and a highly nominalised vocabulary adopt any of the features of the narrative - a highly interpretive account with its actors, agents, scene and motives? White (1981) has argued that narratives could be the solution to the problem of translating knowing into telling - "the problem of fashioning human experience into a form assimilable to structures of meaning that are generally human rather than culture-specific" (p. 1). More fundamentally, given that the community of practice inhabited by scientists is, for the average person, akin to a foreign culture, White points to a crucial role for narrative when he argues that:

We may not be able to fully comprehend specific thought patterns of another culture, but we have relatively less difficulty understanding a story coming from another culture, however exotic that culture may appear to us (p. 1).

In agreement with the above idea, Gough (1993) argues that science fiction texts should be integral to both science and environmental education and that narrative strategies of fiction may be more appropriate for representing science than the expository textual practices that have dominated science and environmental education to date. It is through literary fiction, he states, that the problems of human interrelationships with environments become intelligible.

It is such arguments that have led us to ask what would it mean to use narrative in science education Hence, in this paper, we explore the potential role that narrative might have not only to communicate scientific ideas but also to generate knowledge and understanding of the ideas and concepts. That is, to explore "the value of the narrative in communicating ideas and in making ideas coherent, memorable and meaningful" (Author, 1998). In short, we aim to make the claim that narrative, potentially offers a communicative tool, which has long been neglected by science educators and is worthy of further re-examination.

\section{What is Narrative?}

Bruner (1986) differentiated between two distinct ways that humans order experience. He called the first one paradigmatic, which refers to organizing thought 
that is logico-scientific, which is based on reasons. The second way that humans order experience, according to Bruner, is narrative and deals with the creation of stories. As he described, narrative is used to refer to: a) a way of sculpting and structuring information through expressions of different media into readily understood forms that guide learners' comprehension; and b) a cognitive mode that learners use to make sense out of information or experience. Narrative then becomes part of how people understand the world they live in and they serve as a way of communicating that understanding to others. The corollary of the status of narrative is, as Graesser, Olde and Klettke (2002) have argued, that it has a privileged status among various types of discourse:

The situations and episodes in narrative have a close correspondence to everyday experiences, so the comprehension mechanisms are much more natural than those recruited during the comprehension of other discourse genres such as argumentation, expository text, and logical reasoning (p. 229).

Although narrative is as old as Aesop, in contemporary culture it is expressed through a growing diversity of different media such as books, plays, films and can be experienced in different ways. Moreover, because of narrative's dominance as a form of communication it has been examined throughout the years in a number of different disciplines such as education, sociology, philosophy, history, fiction, film and others. For instance, Chatman (1978) in her book Story and Discourse, defined narrative and described the ways in which it can be actualized:

Narrative is basically a kind of text organization, and that organization, that schema, needs to be actualized: in written words, as in stories and novels; in spoken words combined with the movement of actors imitating characters against sets which imitate places, as in plays and films; in drawings; in comic strips; in dance movements, as in narrative ballet and in mime; and even in music (pp. 117-118).

However, this paper is concerned with narratives realisation in text, as in stories. In this form, three authors in particular, (i.e., Chatman, 1978; Toolan, 2001; Norris, Guilbert, Smith, Hakimelahi_\& Phillips 2 2005) have conducted an extensive functional analysis ${ }_{2}$ which is relevant to our interest on the constituents of narrative and their function. A summary of the major features of their analysis is presented in Table 1. 
For Chatman (1978) there are three necessary components of a narrative: a) a story, described as chain of events; b) the existents that are the characters or items of setting; and c) a discourse, which refers to the means by which the content is communicated. In contrast, Norris et al., (2005) in a significant meta-analysis of narrative present a view of narrative whose concern is the past and whose purpose is to help us better understand the natural world. According to Norris et al., (2005) narratives include eight elements: events, a narrator, narrative appetite, a time, structure, agency, purpose, and a reader. Norris et al., (2005) view all of these elements as essential components of any narrative and suggest that the absence of certain elements such as a narrator, distinguishes a chronicle from a narrative. Significantly, their definition of agency restricts it solely to human beings or moral agents - an interpretation which would preclude the use of narrative in science.

For Toolan (2001), "narrative is a perceived sequence of non-randomly connected events, typically involving, as the experiencing agonist, humans or quasihumans, or other sentient beings, from whose experience we humans can learn" (p. 8). Whilst Toolan shares many of the elements of Norris et al., (2005), his definition is restricted to five elements although their definitions are essentially the same. Chatman's (1978) description of the elements of narrative is again somewhat similar. An important distinction from the other two is that Chatman's notion of agency recognises that it is possible for 'things' to cause events or be affected by events; things that need not be solely human. Chatman, too, draws a distinction between the author, the person who devised the story, and the person who narrates the story. Whilst this difference is subtle it recognises that stories are used to communicate events and that telling the stories of others is one means of knowledge transmission. Table 1 summarizes the three views about the main features of narrative.

An examination of the main features of Table 1 demonstrates that while there is an agreement amongst the three points of view in some features such as events, times $_{2}$ and agency there is disagreement about others. Nevertheless, despite the obvious differences in the three definitions there exists some similarity. All three definitions state that narratives should include the following components: events, time, a narrator and agency. Moreover, with respect to the role of the agency all three definitions are in agreement stating that it is actors who cause and experience events. There are, however, differences in how each author defines these components. For 
Narrative in Science

example, all three authors state that narratives are made of connected events but only Norris et al., (2005) argue that these events need to be in chronological order. More fundamentally, there is disagreement on the nature of the agency. Norris et al., (2005) argued that the actors must be human beings or other moral agents; Toolan (2001) referred to the agents as humans, or quasi-humans, or other sentient beings, and Chatman (1978) stated that agents could be material objects. Our view, for reasons that will be exemplified subsequently, is that agents can be objects from the material world in that entities affect one another - a region of high air pressure produces stable air and high temperatures, light is dispersed by a raindrop to produce a rainbow etc. In this sense, we would concur with Ogborn et al., (1996) who argue that scientific explanations are analogous to 'stories' in that they invent a cast of protagonists which enact a sequence of events which have consequences or purposes.

Likewise, whilst Norris et al., (2005) agree with Toolan (2001) on the existence of a narrator, the way the narrator's role is described differs. In particular, Norris et al., (2005) argue that the narrator is the agent who determines the purpose of the story and the sequence of events. Chatman's (1978) position contradicts this view as she makes a distinction between narrated narratives and non-narrated narratives, suggesting that the existence of a narrator is not a necessary component of the narrative. Rather, Chatman (1978) makes a distinction between the author, the one who devised the story, and the narrator who relates the story, an action that Norris et al., (2005) attribute to the narrator as one and the same. Another difference between the three definitions concerns the purpose that narratives serve. Neither Chatman nor Toolan suggest that narrative should have a purpose. Norris et al., (2005) though, argued that the purpose of narratives is to help people understand the natural world. Whilst this is undoubtedly the primary use of narrative in science providing a forensic analysis not only of what we know but how we know, we will argue that one of the other function of narrative is epideictic providing a celebration of the wonder and awe of the scientific account of the material world.

As for the structure of narratives, Chatman's (1978) definition does not point to any specific requirement, while Norris et al., (2005) state that narratives typically start with imbalances and end in success or failure. Of these two, Toolan's (2001) definition is more in agreement with Norris et al., (2005) and states that narratives are expected to go somewhere with some sort of resolution or conclusion provided. Toolan (2001), however, does not make any reference to as how narratives should 
begin. Norris et al., (2005) introduce a novel but related element here - the notion of narrative appetite - that is the ability of the text to create a desire to know what will happen and which is a feature that neither Toolan (2001) nor Chatman (1978) make any reference to in their definitions. Our view is that whilst the creation of narrative appetite is an important component to engaging the reader - a literary effect that is used as a means of engagement, it is not an essential component.

Finally, Norris et al., (2005) explicitly introduce the requirement for the reader to interpret the text as a narrative as another component of narrative. Chatman (1978) also makes a reference to the audience responding with an interpretation, though not necessarily a 'narrativised' one. Toolan (2001), however, has no such requirement.

From this analysis, two questions emerge for us. First, what are the necessary components, if any, of narrative that may be of value to science education? And, second, are some components of greater importance than others? Our view of the necessary components of narrative draws on our meta-analysis of these authors' work and is presented in Table 2. Such a view, we argue, would permit narrative a role in science - one whose implications will be discussed later. In what follows, we draw on a range of examples to make the case for this representation of narrative in science.

First, we would argue that the purpose of narratives is not just to help us understand the human world, as Norris et al., (2005) state, but also to understand the natural world. For if there is any value to use narrative in science it must include gaining an understanding of not only the human and social world but also the natural world, which is populated with non-human agents. At its core ${ }_{2}$ science is about developing causal explanations of the material world - what is causing global warming, why do people get AIDS, what causes a rainbow and many more. Causes are commonly modelled on the action or agency of one object on another. Canonically, this is associated with a person but is commonly projected onto objects endowing them with agency. Agency, however, should not be reduced to simple causation in order to distinguish physical behaviours brought out by scientific laws, and the effects of human behaviours for which we hold them morally responsible - the key and necessary feature of agency is intentionality. Agency is then inherent to all causal action and not just to human agents. Correlation explanations, in contrast, lack agency. Why is the red sky the shepherd's delight? Why does the light go out when the door slams? Without a mechanism there can be no agency making it impossible to construct a temporal history, which is an essential part of the causal and narrative 
explanation. This is not to say that all explanations are narratives or vice versa. Rather, we suggest that the distinguishing feature between narrative and expository text is the presence or absence of a narrator. All that is required is that the presence of a narrator can be inferred. Here, Norris et al.'s (2005) make a significant point about the interpretive role of the reader, who, must first recognise that a text is a narrative, at least implicitly.

So far we focused our attention on defining what narrative is and identifying its essential constituents. Another important aspect of this work is exploring what the literature suggests about the role and effect of narrative on people's retention on ideas. The next section of this paper is devoted to describing the findings of empirical research on the use of narrative in education and its effects on learning.

\section{Uses and Effects of Narrative}

Several philosophers, educators and researchers have pointed to the value of the use of narratives in learning and understanding the world in which we live (Coles, 1989; Author, 1998; Taylor, 1982; Thorndyke, 1977; William, 2000). In particular, William (2000) stated that narrative text (i.e., fiction) is easier to comprehend and remember than expository text (i.e., factual and informational material). According to Taylor (1982), expository texts are usually "organized according to a hierarchical pattern of main ideas and supporting details" while narrative texts are usually "organized according to a sequential pattern of events that follows the conventions of a story grammar" (p. 323). Ogborn et al., (1996) argued that:

Stories are easy to remember because one part readily evokes the next and the need for resolution, which the narrative structure sets up, involves us as hearers and readers, willy-nilly. But at the deeper level we can think of the story as a knowledge carrier (p. 66).

Gough (1993) suggested that the significance of stories (i.e., fictional narratives) for science and environmental education is associated both with their content but also with their form, given than literary fictions models the narrative strategies that humans use in order to make sense of the world.

A few studies compared the effects of narrative on learning, and provide evidence to support the argument that narrative structures enhance retention and comprehension (e.g., Englert \& Hiebert, 1984; Taylor, 1982; Thorndyke, 1977). 
Englert and Hiebert's (1984) study investigated the effects of four types of expository text on the comprehension performance of children and third and sixth grades of three ability levels. As the researchers described, the four text structures that were used in their study were: description (specifies an object's, person's, animal's or event's characteristics and attributes), enumeration (a series of facts, details), sequence (a series of events related to a process is presented in chronological order) and comparison/contrast (two or more events, objects, individuals are compared according to their likeness and differences on one or more attributes). The findings of this study revealed that the sequence and enumeration were the most salient to children while description and comparison/contrast were the most difficult text structures for both third and sixth grade children to understand. As the researchers explained, it is possible that enumeration (i.e., listing of points) constituted a powerful text structure because the process of recognizing details was like filling in slots in memory. Sequence, on the contrary, may have constituted a powerful text structure because of the children's familiarity with time-based structures in stories (Englert \& Hiebert, 1984). The findings of this study support the argument that the structure of

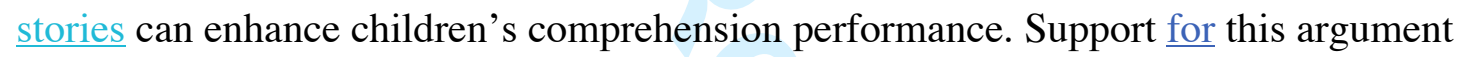
also has been provided by other studies related to science that have produced similar results (e.g., Maria \& Johnson, 1989).

A research study carried out by Maria and Johnson (1989) examined the effect of different types of texts on seventh and fifth graders' learning related to the scientific reasons for seasonal change. Expository and soft expository text - a 'hybrid of narrative and expository text' (p. 329) - were used for the purpose of this study. As the authors reported, three tests were used in this study: a vocabulary multiple choice test was used as one pre-test of prior knowledge about the topic of seasonal change, a misconception multiple choice test, given as a pre-test, immediate post-test and delayed post-test and an application tests, which was given as an immediate and delayed post-test. The results of this study indicated that the subjects had understood the scientific explanation of seasonal change better with the soft expository text, which included narrative, than the expository text.

A study within the context of science education was carried out by Negrete (2003) in order to determine the efficacy of a collection of short stories with scientific 
Narrative in Science

content as means for communicating scientific ideas. Specifically, this study explored $\underline{\text { the question of how efficient are narrative texts compared with factual ones in }}$ communicating science and by which of these two written expressions does the information obtained stay longer in the memory. The participants of this study were a group of 40 undergraduate students that were divided into two sub-groups: one reading short stories with scientific themes written by famous writers (Primo Levi and Anatoly Dnieprov) and the other lists of scientific facts coming from the stories. Quantitative and qualitative data analysis showed that narrative information was retained for lengthier periods than factual information in long-term memory. Moreover, the analysis of the performance of the narrative group showed that individuals were more likely to remember scientific information when that was central to the development of the story. Also worthwhile noting is that the individuals in the narrative group quoted verbatim literary phrases, analogies, metaphors and irony when retelling a story, which according to the researcher, suggests that people retain information when this is presented in an attractive way to them.

In agreement with the above, Norris, Guilbert, Smith, Hakimelahi and Philips (2005) state that the value of proposals to use narrative in science "rests on the existence of a narrative effect that enhances memory, interest, and understanding" (p. 356). Solomon (2002) suggested the use of historical stories about science for the purpose of increasing student motivation and enjoyment and also for facilitating ethical discussion (cf., Norris et al., 2005). Meyer (2008) used storytelling as a way into the students' personal experiences with particular phenomena and the sharing of stories as a way to "trespass within science discourse", and which was effective in engaging female students (p. 467)

Conle (2003) explored various narrative practices in the classroom and highlighted the different forms of engagement that those practices prompt. An example of such narrative practice is the experiential teaching stories in teacher preparation described through an activity where the researcher (instructor) started the class by having the student listen to a song about the ongoing war in Ireland, and then asked them to share personal stories about the realities of war. As the researcher described, something wonderful happened to the students who began sharing painful $\underline{\text { stories and which could be related to the anguish in the song. In discussing the impact }}$ of narrative on this activity, the researcher stated that the act of telling, was 
particularly important because the students tried to tell and write all they remember and during this act they are likely to remember or discover incidents not held in mind at the outset of the telling, which might even change the story or prompt a new understanding of it. Another example of narrative practice, as described by Conle (2003) is journal writing, as she prompted a preservice teacher to create a story she constructed from events in her life and which lead her to a particular understanding about her life, her choice of career and was important for her professionally.

Such narrative practices, Conle (2003) argues have the potential to produce five outcomes: a) advances in understanding (e.g., productive meaning making as the result of narrative encounters); b) increased intepretive competence (e.g., competence in finding multiple interpreations of a particular phenomenon or event); c) richer practice repertoires (e.g., narrative repertoires that become part of one's personal practical knowledge); d) changes in life (e.g., autobiographical narratives cause changes in personal lives), and, e) visions gained (e.g., moral modeling agendas).

In the next section we explore the idea of using one such narrative practice the use of fictional text - narratives - for the purpose of communicating explanations in science through some examples of narrative text and we then discuss the $\underline{\text { implications of this proposition for theory, practice, and research. }}$

\section{Narrative Explanations}

Our interest in the role of narratives to provide scientific explanations is built upon suggestions of the recent reform report by the American National Academy of Education's committee on science education (Duschl, Schweingruber \& Shouse, 2006) calling for improvement in K-8 science, reform recommendations proposed by the National Science Education Standards (National Research Council, 1996) and the Beyond 2000 (Author, 1998) reform document, that suggest an emphasis on the use of evidence and explanation, scientific knowledge development and the discourse of $\underline{\text { science. }}$

Explanations and explanation processes have been examined by linguists, philosophers, historians, psychologists, sociologists, and science educators. The focus has been wide ranging and includes ideological, historical, educational, psychological and epistemological perspectives. The foundation for discussions on scientific explanation has been Hempel and Oppenheim's (1948) Deductive-Nomological model for scientific explanations. According to this model, there are four conditions of adequacy of scientific explanations: a) the explanations must be a valid deductive 
Narrative in Science

argument; b) the explanans must essentially contain at least one general law; c) the explanans must have empirical content; and, d) the sentences constituting the explanans must be true (Hempel, 1966, p. 51). Cartwright (1983) discussed how explanations are used to explain how the world works:

This picture of how nature operates to produce the subtle and complicated effects we see around us is reflected in the explanations that we give: we explain complex phenomena by reducing them to their more simple components (p. 58).

Bechtel and Richardson (1993) referring to the construction of explanations stated that when we explain "we shift down from the system to its parts in order to explain how the system does what it does" (p. 231). What would it mean then to use narrative to explain how 'systems' work in science?

Ogborn et al., (1996) suggested that scientific explanations have an underlying structure analogous to that of a 'story', as there is a world of protagonists that have powers of action. Explanations, they suggest, can be thought of as:

$\ldots$...stories in which actors play out their roles, and we can think of the actors (the entities) as the things which the student has to learn about. An explanation of (say) motion as produced by gravity fits the same form as one about insulin controlling sugar level in the blood (p. 47).

These protagonists of the story, as they explained, enact a sequence of events, which has an outcome, the phenomenon to be explained telling us how something or other comes about. What follows are some examples of pieces of narrative text that provide explanations.

The following piece of popular science offers an explanation of the origin of the elements.

But if all these examples of our cosmic connectedness fail to impress you, hold up your hand. You are looking at stardust made flesh. The iron in your blood, the calcium in your bones, the oxygen that fills your lungs each time you take a breath-all were baked in the fiery ovens deep within stars and blown into space when those stars grew old and perished. Every one of us was, quite literally, made in heaven (Chown, 1998,p.62). 
This piece of popular science states that all of the atoms in our blood are the result of a violent reaction in the interior of old stars. As simplistic as the narrative may be it has a set of imagined entities - stardust, flesh, iron, oxygen and the hot interiors of stars. The latter acts (by some unexplained means) on the atoms in stars to produce stardust, which in turn becomes flesh. There are events, structure, agency and its purpose is to explain the origin of the elements. More fundamentally, the personalised tone endows it with a sense of a narrator providing an essential constitutive element of a narrative.

To exemplify these characteristics we have chosen selected extracts from two contrasting pieces of popular science writing and from the classroom. The first of these is a piece from Primo Levi's book, The Periodic Table, on the Carbon atom. Levi (1995) begins this chapter by introducing his principal character.

Our character lies for hundreds of millions of years, bound to three atoms of oxygen and one of calcium, in the form of limestone: it already has a very long cosmic history behind it, but we shall ignore it. At any moment which I, the narrator, decide out of pure caprice to be the year 1840 - a blow of the pickaxe detached it and sent it on its way to the lime kiln, plunging it into the world of things that change.

This introduction serves a range of functions. First, it introduces the principle actor the unknown entity about whom the story is to be told. In making him, her or it an unknown, the piece serves to generate narrative appetite. Who is this character bound to three other atoms? What will happen to him, her or it? Second, it locates the events clearly in the past situated where it is because of a previous chronology, which will not be explained. At the same time it signals that a chain of events will take place by referring to an imminent event that is about to occur. This piece also serves the dual function of laying down a structure for the work flagging to the reader that this is the beginning of a tale to be told providing the vital literary clue that what follows is essentially a narrative. Finally, the piece introduces a narrator who is the raconteur of the events that are to follow. Such is the ingenuity of this introductory paragraph that the only component missing of our required components is a sense of purpose omitted essentially to sustain a sense of mystery and intrigue necessary to generate narrative appetite. 
Narrative in Science

Primo Levi's purpose is never explicit but most would concur that it is essentially to tell the story of the carbon cycle narrating how this atom is first transformed into carbon dioxide, then caught by the wind, breathed in by a falcon and then brushing against a leaf, penetrating its inner structure, adhering to a large and complicated molecule is finally separated from its oxygen to become part of a molecule of glucose. His major focus, however, is to generate a sense of wonder at the chemical process that is photosynthesis - a process that he never actually names. As a chemist, where most chemical reactions have to be initiated either by heating or pressurising the constituents or both, his tale emphasises the fact that all this happens at the temperature and pressure of the atmosphere, and gratis. This wonder is sustained by pointing to the other feature rarely mentioned in standard expository texts that:

Carbon dioxide... which constitutes the raw material of life.... is not one of the principal components of the air but rather a ridiculous remnant, thirty times less abundant than argon. The air contains 0.03 percent; if Italy was air, the only Italians fit to build life would be, for example, the fifteen thousand inhabitants of Milazzo in the province of Messina.

Undoubtedly $_{2}$ Levi here uses analogy to great effect. But, more fundamentally, his tale has a very distinct purpose. On one level it is a description of the carbon cycle. At another level the text serves as a generator of a sense of awe and wonder of the achievements of the natural world, its complexity and the interrelatedness of the events on which we humans are fundamentally dependent. Thus, with its multiple purposes, this text clearly contains all of the constituents of a narrative text instantiating that it is possible to communicate scientific ideas in this form. Others use narrative constituents to similar effect. Thus, Dawkins (1986) begins his account of the Blind Watchmaker with the following piece to generate narrative appetite.

It is raining DNA outside. On the bank of the Oxford canal at the bottom of my garden is a large willow tree, and it is pumping downy seeds into the air. There is no consistent air movement, and the seeds are drifting outwards in all directions from the tree. Up and 
down the canal, as far as my binoculars can reach, the water is white with floating cottony flecks, and we can be sure that they have carpeted the ground to much the same radius in other directions too.

The opening sentence is fundamentally oxymoronic - DNA not being something which normally rains.

Russell Stannard (1993) likewise, in his book Here I am, written for children, uses such effects in the battle between Phusis, the heroic defender of the Earth, and the Head Exterminator whose task is to dispose of the Earth.

'Ah, but do you know how many basic elements they're made up from?'

He [the Head Exterminator] shook his head.

'Ninety-two,' she said.

'Ninety-two?' he repeated. I don't believe it. You're saying you start off with just ninety-two different kinds of thing - elements did you call them? And from ninety-two, you make hundreds of thousands of different ... ?'

'That's right.'

'No kidding? Most universes have vast, vast numbers of basic building blocks. A real headache trying to keep track of them all. But you say. . .'The Judge shook his head. He found this very hard to swallow.

Such contradictions between the observations of the senses and the underlying sense are a common literary device used by many popularisers of science. Marshall Fox, for instance, reporting the discovery of electric light highlights the contradiction between the fragility of the source and the magnitude of the effect.

Edison's electric light, incredible as it may appear, is produced from a little piece of paper - a tiny strip of paper that a breath would blow away. Through this little strip is passed an electric current, and the result is a bright, beautiful light, like the mellow sunset of an Italian autumn.

Likewise, Natalie Angier (1995) one of the leading American popularisers of science highlights the contradiction between the outward appearance of animal behaviour and 
its actual reality in her book The Beauty of the Beastly:

Ah Romance. Can any sight be as sweet as a pair of mallard ducks gliding gracefully across a pond, male by female, seemingly inseparable? Or, better yet, two trumpeter swans, the legendary symbols of eternal love, each ivory neck one half of a single heart, souls of a feather staying coupled together for life? Coupled for life - with just a bit of adultery, cuckoldry, and gang rape on the side.

Alas for sentiment and the greeting card industry, it turns out that, in the animal kingdom, there is almost no such thing as monogamy. As a wealth of recent findings makes as clear as a crocodile tear, even creatures long assumed to have faithful tendencies and to need a strong pair bond to rear their young in fact are perfidious brutes.

Such effects are undoubtedly effective at generating narrative appetite and would seem to be an essential requirement of any text that seeks to engage and hold its reader. However, there is an important distinction between many of these texts and the first example of narrative text that we described earlier (i.e., Periodic Table). Such texts mix narrative and expository text using the narrative text to sustain the reader's engagement. Thus, Dawkins (1985) continues his introduction in the Blind Watchmaker with the following piece of explanation:

...so why did I say that it was raining DNA rather than cellulose? The answer is that it is the DNA that matters. The cellulose fluff, although more bulky, is just a parachute, to be discarded. The whole performance, cotton wool, catkins, tree and all, is in aid of one thing and one thing only, the spreading of DNA around the countryside. Not just any DNA, but DNA whose coded characters spell out specific instructions for building willow trees that will shed a new generation of downy seeds. Those fluffy specks are, literally, spreading instructions for making themselves. They are there because their ancestors succeeded in doing the same. It is raining instructions out there; it's raining programs-it's raining tree-growing, fluff-spreading, algorithms. That is not a metaphor, it is the plain truth. It couldn't be any plainer if it were raining floppy disks.

The fundamental problem with Dawkin's writing here is that there is no causal 
explanation. Without this, there can be no sense of agency, no history and no narrative structure. In short, it is a descriptive text containing many, albeit striking, metaphors, which multiply describe a single process but provide no causal explanations. Likewise, Angier continues her opening narrative piece with a descriptive element that contains no causal explanations.

Biologists traditionally believed, for example, that up to 94 percent of bird species were monogamous, with one mother and one father sharing the burden of raising their chicks. Now, using genetic techniques to determine the paternity of offspring, biologists find that, on average, 30 percent or more of the baby birds in any nest were sired by someone other than the resident male. Indeed, the great challenge these days is to identify a bird species not prone to such evident philandering.

Later in the piece, she returns to the narrative using an embedded narrative as an exemplar of her point.

Come the spring breeding season, the [chickadee] flock breaks up into pairs, with each pair defending a territorial niche and breeding in it. On occasion, however, a female chickadee mated to a lowranking male will leave the nest and sneak into the territory of a higher-ranking male nearby. That cheating chickadee ends up with the best of both worlds: a stable mate at home to help rear the young, and the chance to bestow on at least one or two of her offspring the superior genes of a dominant male.

These pieces offer only a few examples of narratives that are used to communicate various ideas of science. The fact that teachers commonly use written narrative as a form of exemplifying science concepts is vividly demonstrated by the work of Ogborn et al., (1996) that examines explanation in the science classroom. Here, for instance, the teacher uses a simple narrative to convey the idea that sound can travel through solids;

Now then I used to have terrible problems using a phone box because I worked up in Scotland in a little village....where the Glenfiddich whisky comes from - so it was a bit nice. And when I used to phone home there used to be a great big clock tower in the 
middle of the village and throughout the summer they would have a piper standing next to the telephone boxes playing the bagpipes so you can imagine what that was like when you were trying to phone home (p. 67).

Such a narrative contains all our essential seven elements including a clear, underlying purpose. More importantly, here the narrative works providing a causal explanation for why it was difficult to hear - the sound of the bagpipes can travel through glass and drown out the sound from the telephone. Ogborn et al., (1996) provide many other examples of how teachers commonly deploy narrative as a means of embedding science concepts suggesting that oral narratives are a vital element of teachers' pedagogic arsenal. Such pedagogical functions of narrative are explored in the next section.

\section{Pedagogical Function of Narrative}

In this section we explore the pedagogical function of narrative as we recognize that there is pedagogical purpose in teaching science with the use of stories but, also, in engaging students in narrative construction. In essence, we examine the potential for a narrative-based pedagogy where narrative plays a central role in the learning process and has implications for the interplay among content, learners and teachers. A narrative-based pedagogy is in conjunction with ideas drawn from the second-generation cognitive science, as discussed by Klein (2006), which considers knowledge as perceptually based, fuzzy, and contextual while language is thought to be largely metaphorical and narrative. Klein (2006) points to a gap between the denotative nature of science text and the expressive nature of human cognitive representation representations and poses the question of how people can learn to read and write stories. The gap between everyday narrative speech and scientific explanation and argumentation, he argues, is mediated by science literacy education through the use of various activities that combine talk and writing (i.e., informal writing, speech-like texts, narrative-argument blends etc).

In agreement with these ideas, Mott, Callaway, Zettlemoyer, Lee and Lester (1996) argue that narrative could well form the basic for entire curricula and propose the design of narrative-centred learning environments that would enable learners to participate in the following activities: a) con-construction: participate in the construction of narratives; b) exploration: engage in exploration of the narrative such 
as examining the characters in relation to their actions; and c) reflection: engage in post-hoc analysis activities through reflecting on narratives subject matter. Through such activities and within the context of narrative-centred learning environments, as the authors suggest, constructivist learning is promoted.

A related classroom example comes out of Gilbert, Hipkins and Cooper's (2005) work, who described the use of narrative materials to support science learning in New Zealand's kura kaupapa Maori schools (i.e., Maori worldview schools) or put differently, the use of stories as a way of making science more "inclusive" for students who find science inaccessible and alien. These schools were first established in New Zealand in the early 1980s initially funded by families and communities and later on by the Government also, to address the problem of the low proportion of Maori children being able to speak Maori and that these children were overrepresented in negative schooling statistics. In an attempt to address the issue of Maori language teaching resources, the researchers developed the Totika (i.e., "right" in English) resources, which are stories containing origin traditions and historical knowledge as well as messages about accepted social behaviour, morals, values, and/or explanations of natural phenomena. The researchers describe various such stories and also pointed to limitations of those (i.e., children's finding it hard to imagine themselves in the stories, stories not being scientific enough etc) to conclude that narrative has a place in science education and could be used as a bridge between narrative thinking the logico-scientific mode of thinking. However, as the researchers suggest, there is a need to come up with "science stories that involve real people (with real feelings and motivations) solving real problems, in ways ordinary people can empathise with" (p. 13).

Narrative can be a useful tool not only in the hands of teachers but also for students as well as means to communicating their understandings of science. Bostrom (2006) examined teachers' and students' narratives in making school chemistry more meaningful to students. Data consisted of interviews with six experienced chemistry teachers and eleven students. Analyses of data illustrated that teachers used narratives from their own lived experience as well as from other people's lives in order to make chemistry more meaningful and also the students used narratives or stories connceted to their own lived experience. These narratives were often used as personal anecdotes, but included historical stories of science, and also units of work that were based on 
Narrative in Science

narrative, such as the class that traced the amount of greenhouse gas emission involved in each stage of manufacture of a chocolate bar. Moreover, as the researcher asserted, the content of narrative analyses showed that narrative made chemistry in class pluralistic in allowing the lived experiences of both teachers and students to interact with the scientific facts, which sugggests a role of narrative as an educational method.

Another pedagogical approach to the use of narratives by students takes place within the context of narrative virtual environments or various models of ICTs which enable chidren to be story constructors and storytellers within the context of

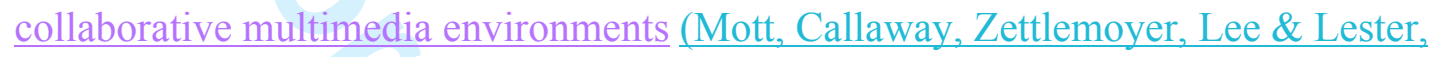
1999; Mott \& Lester, 2006). Mott and Lester (2006) described the virtual world of CRYSTAL ISLAND, an inquiry-based learning envronment for middle school students:

CRYSTAL ISLAND features a science mystery set on a recently discovered volcanic island where a research station has been established to study the unique flora and fauna. The user plays the protagonist attempting to discover the origins of an unidentified infectious disease at the research station. The story opens by introducing her to the island and the members of the research team for which her father serves as the lead scientist. As members of the research team fall ill, it is her task to discover the cause of the outbreak. She is free to explore the world and interact with other characters while forming questions, generating hypotheses, collecting data, and testing her hypotheses. Through the course of her adventure she must gather enough evidence to correctly choose among candidate diagnoses including botulism, cholera, giardiasis, paralytic shellfish poisoning, salmonellosis, and tick paralysis as well as identify the source of the disease (p. 7)

It is clear that such examples of narrative construction by students support their engagement in hypothesis building and testing through data collection and analysis for the purpose of constructing scientific explanations.

As these classroom examples suggest narrative in teaching and learning can take various forms such as storytelling, role-playing, autobiographical writing, simulations, etc and can take place in a variety of learning environments. To address questions associated with these various uses and forms of narrative in science and the potential of a narrative-based pedagogy we discuss implications for theory and 
Equally important with the design of such curricula, we suggest, is supporting teachers develop 'participatory' relationships with the materials that enables effective modification, learning and use (Schwarz, Davis, Kanter \& Smith, 2006). In essence, we argue that it is imperative that teachers develop specific pedagogical content knowledge that would enable them to approach the narrative-based curriculum materials flexibly and make adaptations to them in order to fit in with their local classroom contexts and instructional objectives.

Moving beyond the implications of the proposition to use narrative in science for theory and curriculum, we argue that this proposition also has implications for teacher education and teacher practices. The main implications of this proposition point towards the need for teacher preparation programs to provide prospective teachers with opportunities to learn science through narratives. Put otherwise, we suggest that narrative texts are incorporated in science methods courses for the purpose of supporting prospective teachers in developing the Pedagogical Content Knowledge (PCK) needed to incorporate effectively narrative texts in their own teaching practices in the future.

Implications of the proposition of the use of narrative in science for research are associated with explorations of the role of narrative in communicating science and the ways in which narrative supports comprehension and facilitates science learning. 
Narrative in Science

Hence, we recommend that future research be directed in the area of narrative use in science aiming at identifying existing fictional narratives that could be used in science and examining the effects of narrative on learning.

Identifying existing fiction and non-fiction narratives used to communicate scientific ideas and exploring their characteristics is an important line of research because these could be used to illustrate the ways in which narratives are structured, organized, and used in certain learning environments. Drawing upon such resources, new ones could be developed exemplifying a wider variety of scientific concepts and used in a wider variety of settings. In addition to identifying existing narratives that could be used in science, it might also be useful to explore the idea of students constructing their own oral or written narratives as way of engaging with and making meaning of natural phenomena and communicating scientific ideas as described in other studies (e.g., Conle, 2003; Meyer's 1998).

Moreover, we argue that there is a need for further large-scale studies that will investigate the ways in which narratives support learning within the context of science. Questions to be answered are ones associated with the impact of narratives on people's understanding of science concepts. Critical questions to be answered are the following: Does the use of narrative lead to an improved retention of the ideas in science? Does the use of narrative lead to an improved conceptual understanding of either or both the concepts of science and the nature of science? Equally important, we argue, is to identify which specific elements of narratives people recall the most and what impact those have on their understandings we suggest that qualitative indepth studies are done to answer questions such as: What specific information do people recall from reading narrative text and which narrative component is associated with that specific information?

\section{Concluding Remarks}

In this paper we attempted to make the case for the use of narratives, as in fiction text, in communicating science as a way of making it meaningful, relevant and accessible to the public. We built our case on Montgomery's (1996) view that the language of science "makes us feel excluded from a certain grown-up world of truth and truth telling” (p. 2) and we drew upon Bruner's (1986) argument that narrative is 
central in how people understand the world they live in and serves as a means to communicate personal understanding to others. We do not claim that the use of fictional narrative in science is the solution to all science education's problems, or the best way of representing scientific information; rather we suggest that narrative is used as one approach to communicating science and representing specific scientific ideas.

An issue of concern is what kind of science is communicated through narratives_as casual accounts or popularisation of knowledge, that are part of the content of science. A crucial question then arises: Is there a danger of portraying an oversimplified picture of science through narratives? Gould (1992) in the Prologue to his collection of articles Bully for Brontosaurs, discussed:

Popularising science is held in such disregard in professional scientific circles that forays into the genre may damage the research careers of budding young scientists. The criticism from the scientific community directed at popularising practices are that they are 'simplifications', 'adulterisations' and focus on the 'whiz bang'. (p. 11)

However, according to Gould (cf., Fuller, 1998), even though criticisms hold true for some popular texts, "accessible science can be reclaimed as an honourable intellectual tradition" and that "any conceptual complexity can be conveyed in ordinary English" (p. 37). The issue then becomes one of how to translate the conceptual complexity of scientific information into 'everyday' language without minimizing its value. Montgomery (1996) suggests that we should "somehow discover or forge a stable plane between scientific and non-scientific speech" (p. 52). Discovering this stable plane between scientific and non-scientific speech and between expository and narrative text, we argue, ought to be the goal and direction of research concerned with the use of narrative in science. Future steps of our work will explore this 'stable plane' as we hope that this paper will provide the basis for intellectual conversations amongst theorists, educators, and researchers about the potential of narrative in communicating science. 
Narrative in Science

Table 1

Three views about the main features of narrative

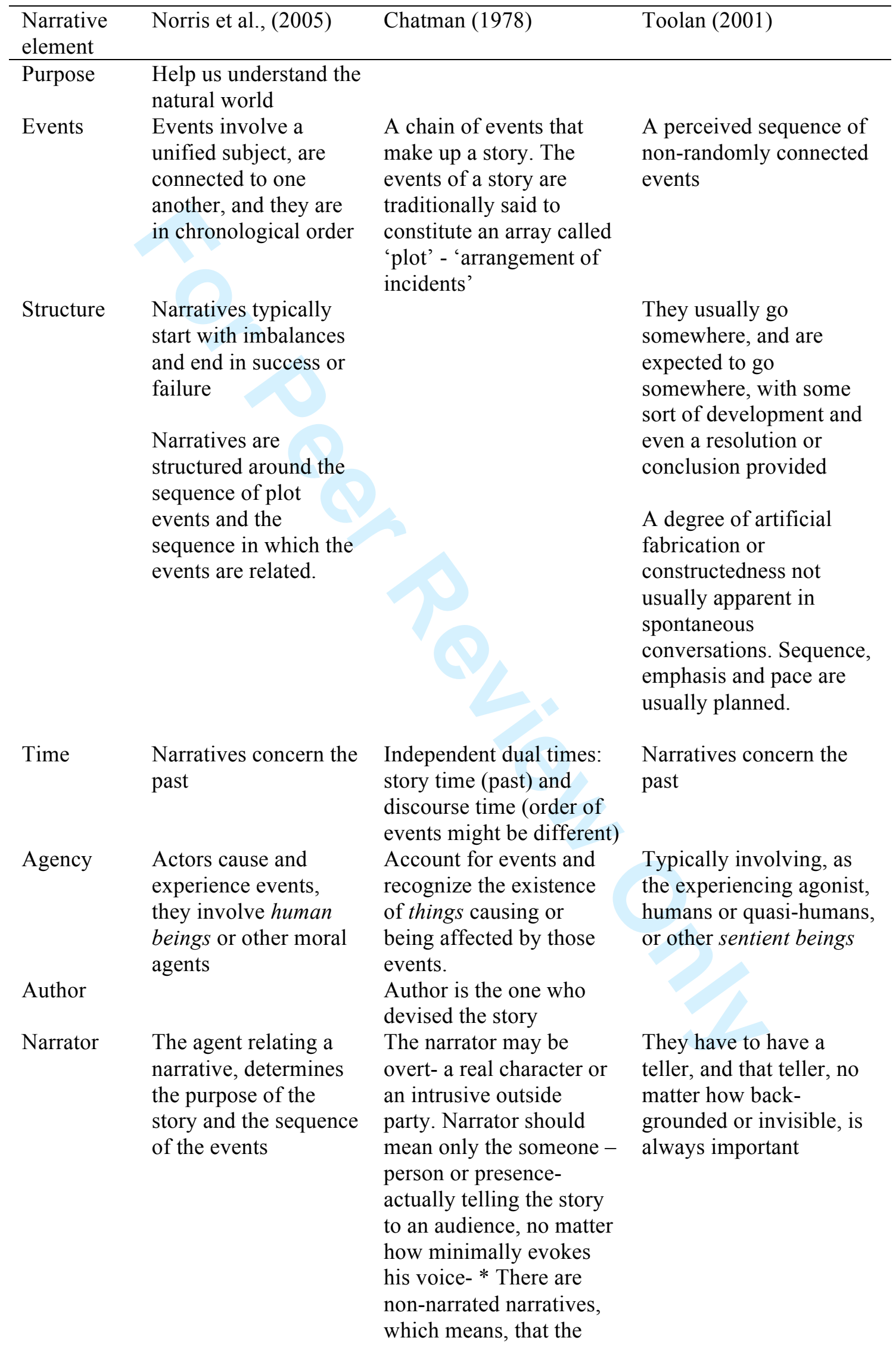




\section{Reader \\ The reader must interpret the text as a narrative}

Narrative Appetite Discourse existence of a narrator is not a necessary component of the narrative The audience must respond with an interpretation: they cannot avoid participating in the transaction

The means by which the story is communicated 
Narrative in Science

Table 2

Necessary components of a narrative

\begin{tabular}{ll}
\hline Narrative Component & \multicolumn{1}{c}{ Description of component } \\
\hline Purpose & $\begin{array}{l}\text { To help us understand the natural and human world. In the } \\
\text { case of the natural world, narratives help the reader to } \\
\text { invent new entities, concepts and some picture of the } \\
\text { scientist's vision of the material world. } \\
\text { A chain or sequence of events that are connected to each } \\
\text { other } \\
\text { An identifiable structure (beginning, middle, end) where } \\
\text { events are related temporally }\end{array}$ \\
Structure & $\begin{array}{l}\text { Narratives concern the past } \\
\text { Actors or entities cause and experience events. Actors may } \\
\text { Time }\end{array}$ \\
either be human or material entities who act on each other. \\
The teller who is either a real character or alternatively, a \\
sense of a narrator. \\
Narrator
\end{tabular}


References

Author. (2001). International journal of science education

Author. (2003). International journal of science education.

Author. (1998).

Author. (2001).

American Association for the Advancement of Science. (1993). Benchmarks for science literacy. New York, NY: Oxford University Press.

Angier, N. (1995). The beauty of the beastly. New York, NY: Mariner Books.

Arnold, K. (1996). Presenting science as a product or as process: Museums and the making of science. In S.M.Pearce (Ed.), Exploring science in museusm. London: Athlone.

Bechtel, W., \& Richardson, R.C. (1993). Discovering complexity: Decomposition and localization as scientific research strategies. Princeton, NJ: Princeton University Press.

Bostrom, A. (2006). Sharing lived experience. How upper secondary school chemistry teachers and students use narratives to make chemistry more meaningful. Unpublished PhD dissertation. Stocholm: Stocholm University.

Bradburne J.M. (1998). Dinosaurs and white elephants: The science center in the twenty-first century. Public understanding of science, 7, 237-253.

Brock, T.C., Green, M.C., \& Strange, J.J. (2002). Insights and research implications. In M.C. Green, J.J Strange, \& T.C. Brock (Eds.), Narrative impact: Social and cognitive implications (pp. 343-354). Mahwah, NJ: Lawrence Erlbaum Associates.

Brock, T.C., Strange, J.J., \& Green, M.C. (2002). Power beyond reckoning. In M.C. Green, J.J Strange, \& T.C. Brock (Eds.), (Eds.), Narrative impact: Social and cognitive foundations (pp. 1-16). Mahwah, NJ: Lawrence Erlbaum Associates.

Bruner, J. (1986). Actual minds possible worlds. Cambridge, MA: Harvard University Press.

Cartwright, N. (1983). How the laws of physics lie. Oxford: Oxford University Press.

Chatman, S. (1978). Story and discourse: Narrative structure in fiction and film. Ithaca, NY: Cornell University Press.

Chown, M. (1998). The cosmic connection. New Scientist, 2159, p. 68. 
Claxton, G. (1991). Educating the enquiring mind: The challenge for school science. London: Wheatsheaf.

Coles, R. (1989). The call for stories: Teaching and the moral imagination. Boston, MA: Houghton Mifflin.

Conle, C. (2003) An anatomy of narrative curricula. Educational Researcher (32), 3 , 3-15.

Dawkins, R. (1986). The blind watchmaker: Why the evidence of evolution reveals a universe without design. London: Penguin Books.

Egan, K. (1986). Teaching as storytelling: An alternative approach to teaching and curriculum in the elementary school. London: Althouse Press.

Feynman, R.P. (1970). Feynman's Lectures on Physics. Boston, MA: AddisonWesley.

Fuller, G. (1998). Cultivating science: Negotiating discourse in the popular texts of Stephen Jay Gould. In J. R. Marting and R. Veel (Eds.), Reading science: Critical and functional perspectives on discourse of science (pp. 35-62). London: Routledge.

Gilbert, J., Hipkins, R. \& Cooper, G. (2005). Faction or fiction: Using narrative pedagogy in school science education. Paper presented at the Redesigning Pedagogy: Research, Policy, Practice conference, Nanyang University Institute of Education, Singapore.

Graesser, A.C., Olde, B., \& Klettke, B. (2002). How does the mind construct and represent stories. In M.C. Green, J.J.,Strange \& T.C. Brock (Eds.), Narrative impact: Social and cognitive foundations (pp. 229-262). Mahwah, NJ: Lawrence Erlbaum Associates.

Gough, N. (1993). Environmental education, narrative complexity and postmodern science/fiction. International Journal of Science Education (15), 5, 607-625.

Gudmonsdottir, S. (1995). The narrative nature of pedagogical content knowledge. In H. McEwan and K. Egan (Eds.), Narrative in teaching, learning, and research. (pp. 24-38). New York: Teachers College Press.

Halliday, A.K., \& Martin, J.R. (1993). Writing science: Literacy and discursive power. London: The Falmer Press.

Hempel, C. (1966). Philosophy of natural science. Englewood Cliffs, NJ: PrenticeHall, 
Hempel, C., \& Oppenheim, P. (1948). Studies in the logic of explanation. Philosophy of science, 15(2), 135-175.

Klein, P.D (2006). The challenges of scientific literacy: From the viewpoint of $\underline{\text { second-generation cognitive science. International Journal of Science }}$ Education, 28(2-3), 143-178,

Lemke, J.L. (1990). Talking science: Language, learning, and values. Norwood, NJ: Ablex Publishing Corporation.

Levi, P. (1995). The periodic table [Translated from the Italian, R. Rosenthal]. New York, NY: Schocken Books Inc.

Maria, K., \& Johnson, J. M. (1989, December). Correcting misconceptions: Effects of type of text. Paper presented at the annual meeting of the National Reading Conference, Austin, TX.

Meyer, K. (1998). Reflections on being female in school science: Toward a praxis of teaching science. Journal of Research in Science Teaching, 35, 463-471

Middleton, S. (1995). Doing feminist educational theory: A post-modernist perspective. Gender and education, 7, 87-99.

Montgomery, S.L. (1996). The scientific voice. New York, NY: Guilford Press.

Mott, W.B., Callaway, C.C., Zettlemoyer, S.L ., Lee, Y.S., \& Lester, C.J. (1999). Towards Narrative-Centered Learning Environments. Working Notes of the 1999 AAAI Fall Symposium on Narrative Intelligence.

Mott, W.B \& Lester, J. (2006). Narrative-centered tutorial planning for inquiry-based learning environments. In Proceedings of the 8th International Conference on Intelligent Tutoring Systems (ITS-2006), Jhongli, Taiwan, 2006.

National Research Council. (1996). National science education standards. Washington, DC: National Academy Press.

National Research Council. (2000). Inquiry and the national science education standards. Washington, DC: National Academy Press.

Negrete, A. (2003). Fact via Fiction. The Pantaneto Forum. 12. Retrieved on April 30. 2008 from http://www.pantaneto.co.uk/issue12/front12.htm

Norris, S.P., Guilbert, S.M., Smith, M.L., Hakimelahi, S., and Phillips L.M. (2005). A theoretical framework for narrative explanation in science. Science Education, $89,535-563$.

Ogborn, J., Kress, G., Martins, I., \& McGillicuddy, K. (1996). Explaining science in the classroom. Buckingham: Open University Press. 
Narrative in Science

Penney, K., Norris, S.P., Phillips, L.M. \& Clark, G. (2003). The anatomy of junior high school science textbooks: An analysis of textual characteristics and a comparison to media reports of science. Canadian Journal of Science, Mathematics and Technology Education, 3(4), (pp. 415-436).

Ricoeur, P. (1981). Narrative time. In W. J. T. Mitchell (Ed.), On Narrative (pp. 165186). Chicago, IL: Chicago University Press.

Schank, R.C., \& Berman, T.R. (2002). The pervasive role of stories in knowledge and action. In M.C. Green, J.J Strange, and T.C Brock (Eds.), Narrative impact: Social and cognitive foundations (pp. 287-314). Mahwah, NJ: Lawrence Erlbaum Associates.

Stannard, R. (1993). Here I am. London: Faber.

Schwarz, C., Davis, B., Kanter, D., Smith, S. (2006). Learning Progressions for Describing Teachers' Use of Curriculum Materials. Presentation made at the Center for Curriculum Materials in Science Knowledge Sharing Institute. Michigan: University of Michigan.

Tallis, T. (1995). Newton's sleep: Two cultures and two kingdoms. New York, NY: St Martin's Press.

Taylor, B.M. (1982). Text structure and children's comprehension and memory for expository material. Journal of educational psychology, 74(3), 323-340.

Toolan, M.J (2001). Narrative: A critical linguistic introduction. London: Routledge. Thorndyke, P. (1977). Cognitive structures in comprehension and memory of narrative disourse. Cognitive psychology, 9, 77-110.

White, H. (1981). The value of narrativity in the representation of reality. In W. J. T. Mitchell (Ed.), On Narrative (pp. 1-23). Chicago, IL: The University of Chicago Press. 